Génét. Sél. Evol., 1986, 18 (4), 367-374

\title{
A Robertsonian translocation in swine
}

\author{
M. SCHWERIN, D. GOLISCH, E. RITTER \\ Research Centre of Animal Production \\ Dummerstorf-Rostock, 2551 Dummerstorf \\ German Democratic Republic
}

\begin{abstract}
Summary
A cytogenetic survey was carried out on fattening male and female pigs of different lines in a local herd and on A.I. boars of German Democratic Republic. In 5 of 66 fattening animals and 4 of 461 A.I. boars analysed, a Robertsonian translocation was observed. The translocation was identified as a 13/17 fusion translocation by the G-banding technique. These animals were translocation heterozygotes with $2 \mathrm{n}=37, \mathrm{XX}$ or $\mathrm{XY}, \mathrm{t}^{+}(13 \mathrm{q}, 17 \mathrm{q})$. The results obtained are discussed.
\end{abstract}

Key words: Fusion translocation, swine.

\section{Résumé}

Une translocation Robertsonienne chez le porc domestique

Une étude cytogénétique a été réalisée en République Démocratique Allemande sur des porcs mâles et femelles à l'engraissement appartenant à différentes lignées et sur des verrats d'insémination artificielle. Une translocation Robertsonienne a été mise en évidence chez 5 des 66 animaux à l'engraissement et chez 4 des 461 verrats d'insémination artificielle. Cette translocation a été identifiée, par la méthode des bandes G, comme une translocation de type fusion 13/17. Les animaux étaient porteurs d'une translocation à l'état hétérozygote avec $2 \mathrm{n}=37, \mathrm{XX}$ ou XY, $\mathrm{t}$ $(13 q ; 17 q)$. Les résultats obtenus sont discutés.

Mots clés : Translocation Robertsonienne, porc.

\section{Introduction}

Robertsonian translocations are distributed widely in cattle. This type of chromosome aberration was first reported as the $1 / 29$ translocation which resulted from a centric fusion between the largest and the smallest autosomes in the Swedish Red and White cattle (Gustavsson \& RockBonN, 1964). Since then, the same or other types of Robertsonian translocation have been found in many cattle breeds. In contrast, in swine 
reciprocal translocations are more common. So, in the last ten years several types of reciprocal translocations were described (Popescu \& Legault, 1979 ; Förster et al., 1981 ; Golisch et al., 1982 ; Gustavsson et al., 1983 ; Popescu et al., 1983). The first information about the occurrence of Robertsonian translocations in swine (Sus scrofa) was given by MiYAKE et al. (1977). In this report we present information about a Robertsonian translocation in swine observed in a local unselected pig herd and in A.I. boars in GDR.

\section{Materials and methods}

Blood samples were obtained from 66 female and male animals of different lines raised on a fattening farm of the southern region of GDR, and from 461 A.I. boars of a breeding station. Each sample $(2.0 \mathrm{ml})$ was incubated at $37^{\circ} \mathrm{C}$ for $48 \mathrm{hrs}$ in $8.0 \mathrm{ml}$ Parkermedium supplemented with $0.1 \mathrm{ml}$ PHA (Welcome) and antibiotics. $1 \mathrm{ml}$ of 0.001 p. 100 colchicine solution was added at $2.0 \mathrm{hrs}$ before the termination of culture. After hypotonic treatment with 0.56 p. $100 \mathrm{KCl}$ solution, cells were fixed in methanolacetic-acid $(3: 1)$, and airdried on a slide glass. Trypsin G-band- (SEABright, 1971) and C-band-techniques (SUMNER, 1972) were applied for additional identification of the chromosomes. A total of 30 metaphase cells from each animal was analysed with the ordinary non-banding method. Those with abnormal complements were further studied by G-banding methods.

\section{Results}

The present chromosome analysis was based on the G-band karyotype established by the standard system of Reading (Ford et al., 1980).

TABLE 1

Results of cytogenetic analysis in a local herd of fattening pigs of different cross breedings lines in GDR.

\begin{tabular}{|c|c|c|}
\hline Chromosome number and karyotype & Number of animals & Percentage $(\%)$ \\
\hline $2 \mathrm{n}=38, X Y$ or $X X$, normal. & 61 & $92.4\langle 83 ; 97\rangle$ \\
\hline $2 n=37, X Y$ or $X X, t^{+}(13 q, 17 q) \ldots$ & 5 & $7.6\langle 3 ; 17\rangle$ \\
\hline Total & 66 & 100.0 \\
\hline
\end{tabular}

Confidence intervals are given at the level 0.95 .

Out of the 66 unselected pigs, examined, 61 had the normal karyotype with $2 n=38, X Y$ or $X X$ (table 1). The remaining 5 animals showed a reduction of the diploid number from 38 to 37 chromosomes in all the cells studied. An additional large submetacentric chromosome was observed in their metaphases (fig. 1). Based on the 


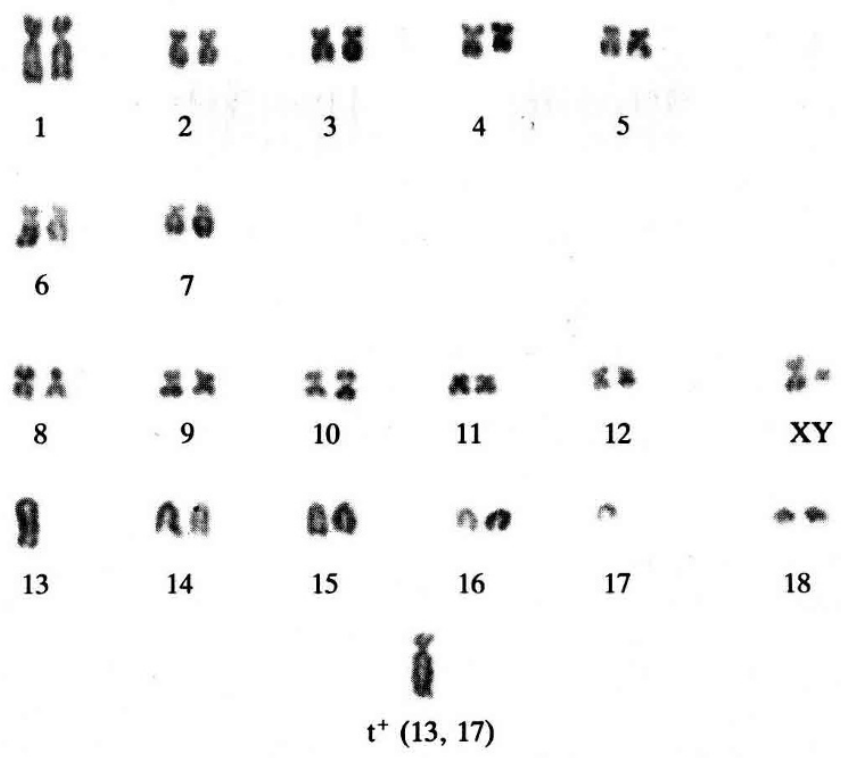

FIG. 1

Giemsa stained metaphase chromosomes and karyotype of a male pig $\left(2 n=37, X Y, t^{+}(13 q, 17 q)\right)$.

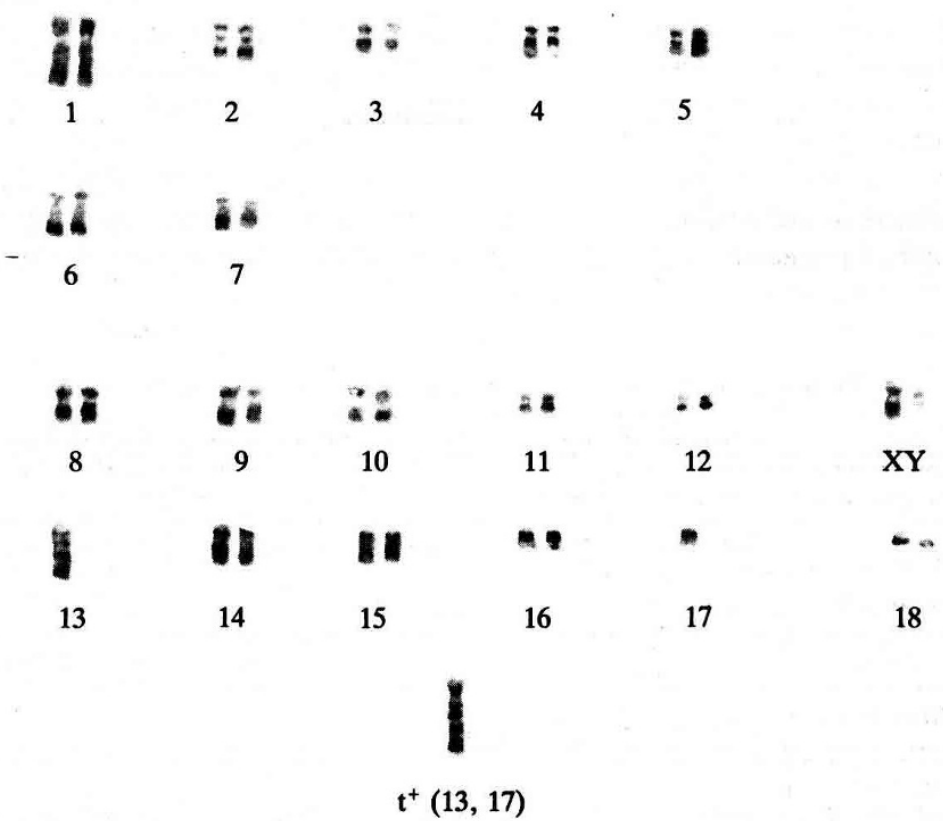

Fig. 2

$G$-banded metaphase chromosomes and karyotype of a female pig $\left(2 n=37, X X, t^{+}(13 q, 17 q)\right)$. 
$\mathbf{N}^{\circ}$ of chromosomes

13

t $13 / 17$

17

a

b

c
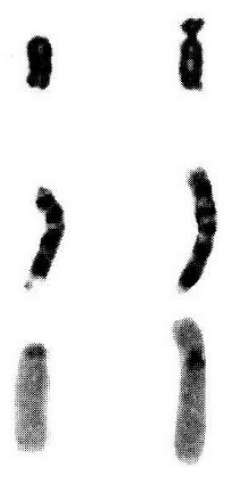

Fig. 3

Cut out chromosomes included in the translocation stained according to various banding techniques (a-normal Giemsa staining, b-GTG-technique, c-CBG-technique).

results of karyotype analysis with G-banding technique it was confirmed that the large submetacentric chromosomes resulted from Robertsonian translocation between the largest acrocentric chromosome and a small acrocentric chromosome. The short and long arms of the fusion chromosome were identified by their sizes and characteristic Gbanding patterns (see fig. 1, 2, 3) as chromosomes of the pairs 13 and 17. The 13/17 translocation also was characterized by having a single centromeric block (fig. 3) of Cbanded constitutive heterochromatin. The detailed karyotype analysis of the fattening pigs examined is summarized in table 1 . The translocation carriers were heterozygotes with the karyotype of $2 n=37, X X$ or $X Y, t^{+}(13 q, 17 q)$.

\section{TABLE 2}

Frequency of the 13/17 Robertsonian translocation in A.I. boars in GDR.

\begin{tabular}{|c|c|c|c|}
\hline Breeds & $\begin{array}{c}\text { Number of animals } \\
\text { analysed }\end{array}$ & $\begin{array}{c}\text { Number of animals } \\
\text { with a normal } \\
\text { karyotype } \\
2 \mathrm{n}=38, \mathrm{XY}\end{array}$ & $\begin{array}{l}\text { Number of animals } \\
\text { with a translocation } \\
\text { karyotype } 2 \mathrm{n}=37 \text {, } \\
\mathrm{XY}, \mathrm{t}^{+}(13 \mathrm{q}, 17 \mathrm{q})\end{array}$ \\
\hline Landrace & 62 & 58 & $4(6.4 \%)\langle 3 \quad ; 15\rangle$ \\
\hline $\begin{array}{l}\text { "Edelschwein " } \\
\text { (Yorkshire) . . }\end{array}$ & 276 & 276 & 0 \\
\hline Crossbreeding lines & 123 & 123 & 0 \\
\hline Altogether . . & 461 & 457 & $4(0.9 \%)\langle 0.3 ; 2.2\rangle$ \\
\hline
\end{tabular}

Confidence intervals are given at the level 0.95 . 
The frequency of the chromosomally aberrant animals was 7.6 p. 100 with a confidence interval (at the level 0.95 ) of $\langle 3.0 ; 17.0\rangle$. Probably this frequency is not representative for the common pig population in GDR.

Because of the lack of information about the family connections of the fattening pigs analysed and with the aim of verifying the estimate of frequency 461 A.I. boars of different races were cytogenetically investigated. The results of this population survey are shown in table 2. The mean frequency of translocation carriers in the A.I. boars analysed is about 8 times lower than in the unselected animals from a local herd which had been studied. However, it is remarkable that this type of aberration was found only in A.I. boars of the Landrace. Among 62 Landrace animals analysed, 4 boars showed a heterozygote 13/17 Robertsonian translocation. In the other breeds investigated, this translocation was absent. In an additional study of familial relationships it could be shown that all chromosomally aberrant A.I. boars have a common ancestor (see fig. 4).

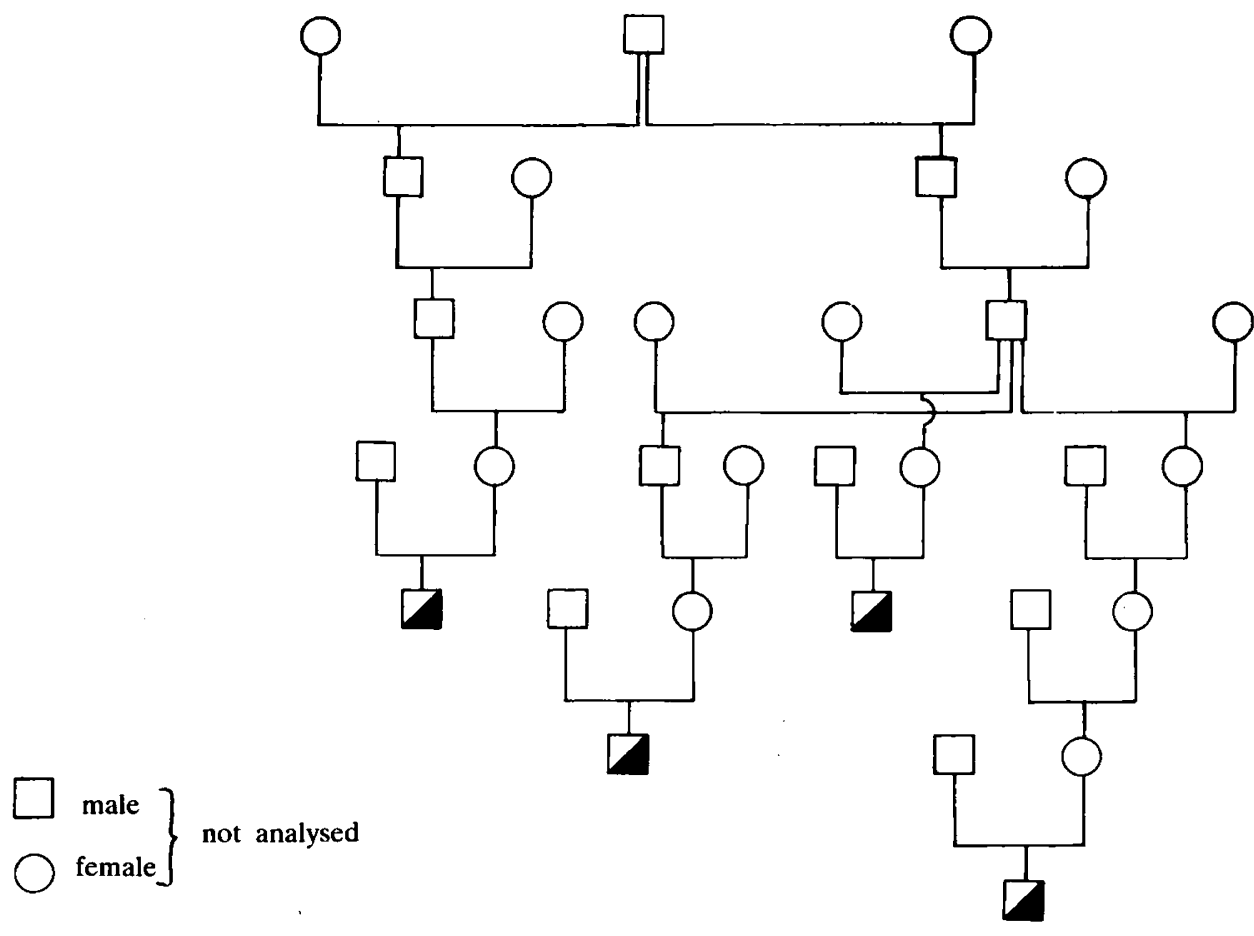

male $\mathrm{t}^{+}(13 / 17)$ heterozygote

FIg. 4

Pedigree of four A.I. boars with a heterozygote 13/17 Robertsonian translocation. 


\section{Discussion and conclusion}

With the observed 13/17 Robertsonian translocation in swine this type of aberration could be described for the third time. The present results supply additional hints that Robertsonian translocation plays a role in the evolution of swine, similar to the previously mentioned 1/29 translocation in cattle (GuSTAvsson, 1979; MAYR, 1977). The 15/17 and 16/17 fusion translocations observed in European and Asian wild pigs respectively (MAYr et al., 1984 ; TroshinA \& TikHonov, 1980) support this assumption.

The mean frequency of the Robertsonian translocation in the sample of A.I. boars was $0.9 \%$. However, with the detailed analysis of breeds it could be shown that the 13/17 translocation probably is present only in the Landrace boars of GDR, and therefore occurs in this race more frequently. Considering its distribution and $\mathrm{C}$ banding pattern, it may be suggested that the $13 / 17$ monocentric translocation occurred earlier in the Landrace of GDR. The increased local use of an aberrant boar in artificial insemination can lead to higher frequency, as could be observed in the present study in a local herd of fattening pigs.

The frequency of 6.45 p. 100 of $13 / 17$ translocation carriers among the A.I. boars of the Landrace indicates that possible effects on performance do not effect an elimination of the translocation from breeding animals.

All the carriers in this study were phenotypically normal, and no abnormality was observed on the condition of their health. To evaluate the potential effects of the 13/17 Robertsonian translocation on other economic traits, especially on fertility, further analyses are in progress now (see Golisch et al., 1986).

Received June 24, 1985.

Accepted June 5, 1986.

\section{References}

Ford C.E., Pollock D.L., Gustavsson I., 1980. Proceedings of the first international conference for the standardisation of banded karyotypes of domestic animals. Hereditas, 92, 145-162.

FörSter M., Willeke H., Richter L., 1981. Eine autosomale, reziproke 1/16 Translokation bei Deutschen Landrasse Schweinen. Zuchthyg., 16, 54-57.

Golisch D., Ritter E., Schwerin M., 1982. Zytogenetische Untersuchungen von Ebern unterschiedlicher genetischer Konstruktionen. Arch. Tierz., 25, 337-344.

Golisch D., RitTer E., Schwerin M., 1986. Die 13/17-Fusionstranslokation beim Schwein und ihre phänotypischen Auswirkungen. Arch. Tierzucht, 3 (in press).

Gustavsson I., 1979. Distribution and effects of the $1 / 29$ Robertsonian translocation in cattle. $J$. Dairy Sci., 62, 825-835.

Gustavsson I., RockboRN G., 1964. Chromosome abnormality in three cases of lymphatic leukaemia in cattle. Nature, 203, 990.

Gustavsson I., Setrergren I., King W.A., 1983. Occurrence of two different reciprocal translocations in the same litter of domestic pigs. Hereditas, 99, 257-267.

MaYr B., 1977. Nachweis der Robertsonschen Translokation im österreichischen Fleckvieh. Wien. Tierärztl. Wochenschr., 67, 186-187. 
Mayr B., Schweinzer D., Geber G., 1984. Nor activity heterochromatin differentiation, and the Robertsonian polymorphism in Sus scrofa L. J. of Heredity, 75, 79-83.

Miyake Y.I., Kawata K., Ishikawa T., Umezu M., 1977. Translocation heterozygosity in a malformed piglet and its normal littermates. Teratology, 16, 163-168.

Popescu C.P., Legault C., 1979. Une nouvelle translocation réciproque t (4 q+;14 q-) chez le porc domestique (Sus scrofa domestica). Ann. Génét. Sél. Anim., 11, 361-369.

Popescu C.P., Boscher J., Tixier M., 1983. Une nouvelle translocation réciproque t, rcp ( 7 q- ; $15 \mathrm{q+})$ chez un verrat "hypoprolifique ". Génét. Sél. Evol., 15, 4, 479-488.

Seabright M., 1971. A rapid banding technique for human chromosomes. Lancet, II, 971-972.

Sumner A.T., 1972. A simple technique for demonstrating centromeric heterochromatin. Exp. Cell. Res., 75, 304-306.

Troshina I., Tiknonov V.N., 1980. The reproductive feature of Landrace $\mathrm{X}$ wild boar hybrids with two chromosomal translocations Tr. $1(16 / 17)$ and Tr. $2(15 / 17)$. Proceedings of the 4 th Europ. Colloq. Cytogenet. Domest. Anim. Swedish University of Agricultural Science, Uppsala, 250-261. 